\title{
The Other Rupture of 1989: The Rushdie Affair as the Inaugural Event of Representations of Post-secular Conflict
}

\author{
NICOLE FALKENHAYNER
}

This text investigates the cultural context in which the Rushdie affair has been embedded 20 years after the event. Remembering the Rushdie affair in Britain has transformed the rupture into a suture, establishing a narrative link between this event, 9/11, the "war on terror" and the London bombings in 2005. In an emergent historiography, I propose, the discursive idiom of a globalised conflict of "the West" and "Islam" is represented within self-descriptions of British multi-ethnic society. The relationship between aspects of multiculturalism and post-secular conflict is analysed as the development of a $(g)$ local memory culture in which globalised developments and localised representations interact. In the last part of this contribution, Jürgen Habermas's proposal for a post-secular public sphere is interrogated concerning the search for a basis for convivial exchange in the face of value pluralism.

\section{Introduction}

The year 1989 appears as year zero for the envisioning of a new global order. The pending demise of the Soviet Union, and the entailing dissolve of the Cold War mapping of the three-world paradigm prompted mediations into the future shape of geopolitics: was the "end of history"1 approaching, or would we end up in a "clash of civilizations"?

Questions concerning the shape of the global gained heightened currency in the social sciences and the humanities in the following two decades; it has often been observed that the term seemed to achieve a character of polysemic elusiveness. In his critical essay on the idiom of globalisation theory, Amin Ash demands a focus on a broad scale of contingent globalising processes, which have to be assessed to thicken globalisation theory's agenda:

Part of the obfuscation lies in the failure to take seriously the amalgam of social processes which we would have to acknowledge if we adopted a broader understanding of globalization. ${ }^{3}$

1. Francis Fukuyama, The End of History and the Last Man (London: Hamish Hamilton, 1992).

2. Samuel P. Huntington, "The Clash of Civilizations?", Foreign Affairs, Vol. 72, No. 3 (1993), pp. 22-49.

3. Amin Ash, "Placing Globalization", Theory, Culture and Society, Vol. 14, No. 2 (1997), p. 127. 
While by no means attempting to delete the polysemic status of the global, as this polysemy adds to the valence of the term, this contribution is concerned with the attempt to acknowledge an amalgam of meaning making which displays localising and globalising trajectories, and addresses social processes under an influence of globalisation processes concerning culture and society. In this context, I will attempt a contextualisation of the media event of the Rushdie affair and the topics its representation opens into.

Where the end of the Cold War epoch prompted the representation of the temporal marker 1989 as the symbol of a rupture of historical time, the 20th-year commemoration of the year zero myth asks us to historicise backwards to this symbolic rupture. While doing this, it is of importance to reconsider the historiographic narrations with which our cultural remembering of the year 1989 is being created. Contested spaces of cultural representations, in which the symbol of 1989 is of importance, include the beginning of the cultural embedding of the phenomenon of global Islamism. In this specific way of representation, the symbolic rupture of 1989 is being linked with that of $9 / 11$.

In the following, I will pay attention to an event which is linked to the shift of conflict rhetorics from ideological to cultural rifts: the controversy surrounding the publication of Salman Rushdie's The Satanic Verses in late 1988 and early 1989. The 20th anniversary of the Rushdie affair has returned its visibility, especially so in the United Kingdom. Remembering the Rushdie affair in Britain was linked to an emergent public historiography that narratively encodes the shock of 9/11, the war on terror and the Al Qaeda attacks in Europe in 2004 and 2005. I wish to show how the narrative closure of the Rushdie affair in a telos towards global jihad inscribes the affair within a British collective memory in which an imaginary of a globalised conflict of the West and Islam is narrated as a self-description of British multi-ethnic ${ }^{4}$ society. The benefit of the heuristics of memory studies lies in the fact that they stress the always contested and preliminary constitution of our access to the past. Like the identity this memory produces, a final constancy is indefinitely postponed by the positioning of memory and identity within time, which re-ambiguates both concepts. Describing the controversy on The Satanic Verses in the context of contemporary British culture, the idea of a post-secular conflict is linked to a shift in the understanding of the universal prevalence of Enlightenment values such as free speech. I show how rhetorical performances during the Rushdie affair pre-formed this shift. This text does not, therefore, seek a comprehensive representation of the Rushdie affair but wishes to show how public historiography in Britain has created certain narratives out of this event. Following a proposal for the strategy of cultural memory studies, this project wishes "not only to describe and explain the functioning of images and symbols, but to interrogate them critically and ask for their destructive potential". 5

4. Here, I will differentiate between multi-ethnic, multicultural and transcultural society. By "multiethnic" I describe simply the fact of several ethnicities living in one society. "Multicultural" refers to policies, programmes and discourses activated by the state and civil society groups to minimise tensions in multi-ethnic societies, as well as theories underlying these. By "transcultural" I refer to the meaning of the term as epistemic category in the social sciences and humanities, as well as to (textual) practices that designate a multidirectional exchange and influence between cultures (Bhabha, Spivak, Welsch).

5. Aleida Assmann, Der lange Schatten der Vergangenheit (Munich: C.H. Beck, 2006), p. 31; author's translation. 
Investigating the development of a specific "clash of cultures" narrative, I point to the political and also ethical implications of the construction of a culturalised image of radical Islam. Highlighting the production of cultural material and, with it, meaning, I point to the ambiguous role of modes of cultural memory such as literature and art, but also theory and scholarly writing, which can partly form but also contest and differentiate proto-understandings. In the last part of the contribution I interrogate Jürgen Habermas's proposal for a postsecular public sphere in the search for a basis for convivial exchange and communication in the face of value pluralism.

\section{Am the New Conflict-Revisiting the Rushdie Affair}

\section{The Satanic Verses: From Text to Event}

When Salman Rushdie, who had achieved critical acclaim with Midnight's Children (1981), published his long-awaited new novel The Satanic Verses (henceforth cited as SV) in late 1988, it made a controversial impact in the realm of cultural politics: one week after its publication, the novel was banned in India. The Muslim opposition MPs Syed Shahabuddin and Kurshid Alam Khan had convinced the government of Rajiv Gandhi that the book was "a direct attack on Islam" - and a danger to civil peace.

How did a postmodern novel, assigned to the genre of "magical realism", perform an attack on Islam so vital that it might endanger civil peace? Srinivas Aravamudan's review of the novel ${ }^{7}$ gives a good reading of the underlying problematic reception of satire, which "reduced the text to event". 8 Rushdie's critics were quick to single out those features of the dense web of the novel's manoeuvres of displacement which were "attacking" Islam, and, as the controversy shows, hit the target without fail: in dream sequences of the already phantastically transformed character Gibreel, the prophet of a newly found religion in the desert city of "Jahilia" - already a satirical play as this name designates in Islamic traditions the state of pagan ignorance of the one god-is given the derogatory name "Mahound", a term from medieval European tradition that equates Mohammed with the devil. This choice of name, the narrative voice explains, will effect the political transformation of derogatory names invented by enemies to strengthen one's own identity (SV 93). Another controversial shift of names and meanings occurs in scenes that narrate stories of a brothel called "Hijab, or the Curtain", and in which prostitutes take on the names of the wives of the prophet. The shift of names from their sacred meanings into satirical displacement was the most often singled out trope of the novel that caused offence to Muslims. The destabilising effect of the text's reception was that of a synechdochal satire, in which the defamed names came to stand for the whole of Islam, as Aravamudan observes:

Even as the satirical victim can respond only in the name of the "whole", with the complaint that satire has defamed a proper name, whether it be

6. Lisa Appignagnesi and Sara Maitland, The Rushdie File (London: Fourth Estate, 1989), p. 42.

7. Srinivas Aravamudan, "Being God's Postman is no Fun, yaar': Salman Rushdie's The Satanic Verses" (Book Review), Diacritics, Vol. 19, No. 2 (1989), pp. 3-20.

8. Ibid., p. 3. 
personal, corporate, political or religious, Rushdie's phenomenological universe works according to the principle that the "whole" it attacks is itself only an accretion of parts, and following the law of association, these parts can always be reconstituted and displaced by others. This law of substitution is itself what threatens the logic, propriety, and indeed property of the "proper" name."

This destabilising of certainty and "wholeness" was also the characteristic of the episode concerning the "Satanic Verses" as a dispelled part of Islamic tradition. It refers to a case of flawed revelation due to which Mohammed had to "edit" the sacred text, as the inclusion of three female goddesses in one verse turned out to be a trick of the devil. The historicity of this episode is in itself a matter of dispute. While some Islamic scholars accept it, others believe it to be an Orientalist fabrication. ${ }^{10}$ This open instability made it a point of entry for Rushdie's own creative deconstruction. Rushdie's rendering of the "Satanic Verses" episode, which makes the inclusion of the goddesses a matter of power politics, posed questions about the relationship between imagination and revelation, as well as their respective stability. The main point around which The Satanic Verses controversy was to evolve, however, was that the actual reading of the book, the polysemy of its text was not the question, the pure existence of an insult was enough to rally against it-and the pure existence of a cry for censorship from Muslims was enough to rally for free speech. It was in this manner that "the text was reduced to event". There was an underlying double-designation of the text in two different idioms of meaning making: the rules of reception of the Western genre of magic realism did not apply when the text was received in an idiom in which the sacred and profane are actual political categories.

Salman Rushdie promptly answered the news of his novel's ban with a scorching open letter to Rajiv Ghandi, defending his rights to free expression and condemning Gandhi's government: Shahabuddin's prompt repartee satirically mocked Rushdie, his novel of "filth", and Anglophile Indian bourgeoisie."1 Where one defended satirising speech against what he perceived to be a dangerous oppression of thoughts, the other was ready to identify this kind of satirical libertarianism with the imperial impression of values, and defended his traditionalising views as resistance to the legacy of colonialism. At the very beginning of the controversy, conflicting understandings of the ambiguous East/West relation set the tone for a dispute that would develop into an international diplomatic affair.

The Satanic Verses' reception by Indian politics and the strong medial visibility of Salman Rushdie as a celebrity persona began to be perceived as a problematic to which many public voices had the urge to respond. The emergent public "eventalization"1.2 of the The Satanic Verses controversy was gathering speed, and paper,

9. Ibid., p. 12.

10. Ibid., p. 43.

11. Ibid.

12. The term "eventalisation", also "eventisation", is a translation of Foucault's "évenémentalisation". It is not the pure description of a "going-on", it is a method for both gathering material and interpretation: an event has to be singled out as a "rupture of the evident", it has to be "raised" above its own historicity. This is the difference from more recent event-theories which presuppose the singularity of the event. In Foucault's terms, this singularity has to be created first. Only after 
and publication indexes. Public communicative processes had singled out the artefact of The Satanic Verses, and were rapidly inscribing this rupture with conflict rhetoric. The notion of eventalisation can also be employed to point to the procedure by which this contribution will continue to approach its object. In order to point to the problematic movements of essentialising notions, one can employ Foucault's notion in the sense of a method for unsettling seemingly evident historical links. To raise a singularity above the structure of historical time, to create an event of singularity, is the creation of a potential for an unfinished set of hyperdirectional links which can be traced from the event. As this polygon around the event cannot appear as a finished entity, it breaks the chain of evidence-representation-attribution. In an "eventalizing" approach, history is not constraining ${ }^{13}$ but points to the procedures by which we constantly create and judge cultural material in order to explain it to ourselves and contest the explanations of others-this text being no exception. Cultural material is being developed within situations of dispute and contestation concerning its positioning and the judgements we make about it. This text will proceed by attempting the construction of such a polyhedron of meaning connected to the event, by which I wish to show how cultural material and judgements evolve in processes of contestation, and by adding my own judgements, which makes this text a part of the "eventalization" of the Rushdie affair which is simultaneously the object of its analysis.

\section{The Satanic Verses Controversy as Media Event}

The already transnational reception of the evolving dispute led to a heightened visibility of the novel within Britain. Muslim organisations formed committees for the defence of Islam and started protest actions, culminating in a staged media spectacle:

When their noisy but peaceful protests and their fairly large but mostly unreported demonstrations got nowhere, a small group of Muslims burned a copy of The Satanic Verses in Bolton on 2 December 1988. That too aroused no national interest. Evidently a London solicitor advised them that they stood a better chance of attracting attention if they burned a copy after duly alerting the national media. They did that in Bradford on 14 January 1989 and secured instant national publicity. ${ }^{14}$

The image of the burning book meant national publicity as it was immediately connected with a dominant Vis out of Western cultural memory. Book burning is so strongly bound to the memory of the Nazi regime that the link cannot be

creating the singular can we reach out to develop its contextualisations in a "polyhedron"-like, multidimensional process of meaning creation. It is therefore a tool to unearth various layers of historical meaning surrounding the event. For Foucault, the process of this gathering of meaning is necessarily unfinished and can only progress towards increasing saturation. Michel Foucault, "Round table Discussion of 20 May 1978", in Michelle Perrot (ed.). L'Impossible prison (Paris: Editions du Seuil, 1980), p. 45.

13. Özkan Ezli, in a talk on "The Eventalization of Culture", Constance, 11 December 2008.

14. Bikhu Parekh, "The Rushdie Affair and the British Press: Some Salutary Lessons", in Free Speech: Report of a Seminar Organised by the Commission for Racial Equality and the Policy Studies Institute (London: Commission for Racial Equality, 1990), p. 3. 
broken, and the image is not fully re-inscribed without the layer of the memory of the totalitarian regime underneath it. The Bradford Muslims were connected, through this spectacle, with totalitarianism and anti-democratic behaviour. Commentators set out to teach British Muslims lessons from European history in an onslaught of media contributions, ${ }^{15}$ which served to harden the fronts between the general British public's opinion as put forward in the media, and the sensitivities of what was now perceived as a fundamentalist, anti-modern minority. Elizabeth Poole sums up the dominant rhetoric of those media publications:

By relating their own views to a discourse of democracy, history and modernity, the press constructed Muslim demands in opposition, as restrictive, archaic, primitive $[\ldots]^{16}$

This coincided with the airing of cultural determinist views on the Qur'an-which were used in a rhetoric in which the values of free speech in particular and the Enlightenment in general were explained with features which were presented as inherent to Christianity, as is exemplified in a statement by the writer Faye Weldon, in which she claimed that the Bible could be the foundation of a decent society, the "monologic" Qur'an, however, certainly could not."

This performative double of minority protest/religious performance was linked in its appresentation ${ }^{18}$ to the larger British public as a shift in minority visibility, which created the category "British Muslim" as an identity tag that crossed out former geographical, linguistics or ethnic categories. As Pnina Werbner has observed, this media image made the "British Muslim" discursively available and set a route on which further markers were inscribed in years to come, which led to the category's current high visibility in the media, cultural production, and academic writing:

Until the publication of The Satanic Verses Muslims in Britain were a silent, apparently compliant and quiescent law-abiding minority [...] Since the Rushdie affair, a series of other crises has disrupted any processes of integration into Britain and induced a sense of widening alienation. The Gulf War, Bosnia, Palestine, Kashmir, Chechnya, September 11, the nuclear confrontation between India and Pakistan, the wars in Afghanistan and Iraq, have all mobilised [...] Muslims on the streets of Britain [... $]^{19}$

This mobilisation, one may add, let to the appresentational connection in the public sphere of the category "British Muslim" with international conflicts.

15. For example, "the Third Reich-style burning of his book", The Independent (7 February 1989); "Islam is going through a period [...] analogous to Europe's own medieval era", The Times (25 February 1989); "Muslim leaders in Britain [...] do not have the racial memory of Nazi book-burning, and they have learned a hasty lesson", The Times (15 February 1989).

16. Elizabeth Poole, Reporting Islam: Media Representations of British Muslims (London: Tauris, 2002), pp. 130-131.

17. Faye Weldon, Sacred Cows (London: Chatto \& Windus, 1989).

18. See for example Alfred Schütz, Der sinnhafte Aufbau der sozialen Welt (Konstanz: UVK, 2004).

19. Pnina Werbner, "Theorising Complex Diasporas: Purity and Hybridity in the South Asian Public Sphere in Britain", Journal of Ethnic and Migration Studies, Vol. 30, No. 5 (2004), p. 905. 


\section{Fatwa}

On Valentine's Day 1989 it was reported by international news agencies that Ayatollah Khomeini had pronounced a fatwa in which he called for the hunting down and execution of Rushdie and his publishers. Salman Rushdie immediately went into hiding - but the man that who disappeared was on view everywhere on newspaper front pages and TV screens. The fatwa was mediated as a provocation of the West. The public outrage was so large that European countries, including Germany and Britain, recalled their envoys from Iran, which they had sent there after the end of the Iran-Iraq war and what seemed like a glimmer of international opening of the theocracy. In the international diplomatic field, the Rushdie affair was a backlash that built up hardening fronts. Typical depictions can be illustrated by a cartoon, which was published in The Guardian in February 1989. Divided by a mountain, Khomeini stands above a crowd of shouting women in hijab, while European heads of state Mitterrand, Kohl and Thatcher shelter Rushdie. Khomeini says "Ahah! There's nothing like a Satanic Foe to bring about unity", to which the European leaders reply "You can say that again!"20 The media established shortcuts between British Muslims, Iran and the Near East, as well as the state of Afghanistan after Soviet withdrawal, which were all strong news items at the same time, thereby contributing to a meta-message about generalised features of "Islam".

A question emerged which points to the cultural turn of the antagonistic relationship in the rhetoric of the Rushdie affair, and which became a megacomplex in Western reflexivity after 9/11: was Islam incompatible with Western libertarian values? Coinciding with this foreshadowed problematic future, the impact of the affair was bestowed with historical weight, as in this statement by Edward Said:

I think the Rushdie affair is much more important than many people think. It can be seen as reflecting the history of the modern relationship between Islam and the West [...] Satanic Verses [...] [is] not one of those things easily reduced to just a Western insult to Islam. ${ }^{21}$

The connection between the history of Islam and the West with the shape of this history in the future bestowed the Rushdie affair with special significance in the public sphere. This significance made it a trope to be kept in archive memoryfor future use. Aleida Assmann, in her comprehensive work on cultural memory, has delineated two different capacities within the cultural function of memory. The configuration and re-configuration of memory incorporates a certain flexibility, which Assmann points to by her differentiation between archive memory and functional memory: The functional memory of a group is the operative part of memory culture; it discusses, disputes, re-narrates, and traditionalises certain stories and tropes. The archive memory stores temporarily de-activated memories-stories and tropes that have become obsolete, or are for other communicative reasons inaccessible. The items in the archive may or may not be retrieved in the advent of newer events that demand interpretation. ${ }^{22}$

20. The Guardian (22 February 1989), p. 6.

21. W.J. Weatherby, Salman Rushdie: Sentenced to Death (New York: Carroll \& Graf, 1990), p. 182.

22. See Aleida Assmann, Erinnerungsräume (Munich: C.H. Beck, 1999), pp. 130-143. 
The advent of global Islamist terrorism in the 21st century and the trope of the home-grown bomber in Britain demanded retrieval, a re-functionalising of the Rushdie affair, which had already been archived in literature.

\section{Rushdie and British Memory}

\section{A New Figuration in Collective Memory: The Home-grown Terrorist}

With the London bombings of 7 July 2005 a new subject enters the social imaginary of Great Britain that dramatised its multi-ethnicity, and it's self-marketing as "multicultural". With the notion of the home-grown Islamist, the global war on terror is transformed into a part of British cultural reality. As one of the most willing partners of the United States in the war on terror, Britain had already preconceived itself as a target. Therefore, the actual event of the attack could be countered in a pragmatic manner of looking for enforced security measures. Immediately after the attack, and ever since, obtaining body scanners for the underground was discussed, which became metonymic for the managerial approach to countering the attack. ${ }^{23}$

On the level of the attack on British collective mentality, idiomatic expressions such as the stiff upper lip and the Blitz war command to stay calm and carry on were recovered out of British cultural memory, and transformed so as to suit multiethnic British society in general and that of the metropolis, specifically. But this line of idiomatic strategy lost momentum with the dawning discovery that this enemy was literally an enemy within, which was at first resisted, as Aiden Kirby notes:

The "home-grown" dimension of this case was so troubling that all the possible international "links" received a great deal of attention. For instance, frequent reference was made to both Khan's and Tanweer's travels to Pakistan and many commentators speculated on the purpose of these trips. One can trace the escalation of speculative reasoning that these trips to Pakistan "must have" included time spent in a Lashkar-eToiba or another Al Qaeda-affiliated training camp. ${ }^{24}$

The dominant figuration of the London bombers which Kirby points to here presented them as well-integrated British lads, who somehow must have been radicalised by some outside, foreign force. This can be interpreted as a figuration that would enable the framing of the London bombings to stay linked and translatable with the globalised American narrative of a threat that was operating in a transnational manner, but could be ascribed an identity outside the social imaginary of the state (as community as well as political entity) to be subsequently targeted. This rhetoric, and the political strategy that took its cues from it, had its origins

23. W. Tinning, "Hi-tech Systems to Bolster Security on Trains. Stations to Test Scanners", The Herald (15 November 2005); D. Leppard, "Superman' Scanner to Spot Bombers", The Sunday Times (5 November 2006); J. Murphy, "New Shopping Centres Will be Bomb-proofed in Terror Crackdown", The Evening Standard (14 November 2007).

24. Aiden Kirby, "The London Bombers as 'Self-starters': A Case Study in Indigenous Radicalization and the Emergence of Autonomous Cliques", Studies in Conflict and Terrorism, Vol. 30, No. 5 (2007), p. 419. 
in the reactions of the American administration following $9 / 11^{25}$ and set the tone throughout the whole Bush II era. These policies and rhetorics have been described as moving the Islamist terrorist into a "state of exception", entailing various meanings of that expression: the terrorist subject exists in an exceptional state that locates him outside of the social imaginary of society, preferably far away from the centres of the world. He is to be fought with measures that also operate within a code of a "state of exception": ${ }^{26}$ the new policy of security.

But the figure of the home-grown terrorist-with all of its societal implications about the failure of integration-problematised the assessment of the London attacks as well as the policies of multiculturalism, and gave the story of global terrorism a British twist. It was not long before British public discussions found a precursor of global liberal outrage due to Islamist provocation which was ignited from British soil: the Rushdie affair.

After the discovery of the home-grown dimension of the 2005 attacks, the Rushdie affair was quickly retrieved from the archive of collective memory, because it enabled an inscription of transnational Islamist fundamentalism within recent British history. The 20th anniversary of the Rushdie fatwa was marked by a number of publications that established a story of British fundamentalism with a global reach. The most recent is the book From Fatwa to Jihad: The Rushdie Affair and its Legacy (2009) by the political scientist and publicist Kenan Malik, but also the pot-boiler Londonistan: How Britain Creates a Terror State Within (2007) by the journalist Melanie Phillips, which points to the harbouring of transnational extremism in London during the 1990s. Where Malik's monograph is an engaged historiographic account and Phillips' effort aims at creating fear, both volumes assess the Rushdie affair as the originator of a British multicultural victim-culture. Promoted by multicultural politics, the values of cultural sensitivities are said to overrun the secular values of the national public sphere.

Today, the Rushdie affair is encoded in a narrative that establishes a temporal parenthesis around it and Islamist terrorism in the West, and creates a model narrative of the threat of global Islamism in the West, into which other events can and have been inscribed as well: the Islamist terrorist attacks in Europe in 2004 and 2005, the killing of the filmmaker Theo van Gogh, and the Danish cartoon controversy. When Kenan Malik describes the staged, and by now iconified, book burning in Bradford, it becomes clear that he is writing out of an interpretative consensus that has encoded the trauma of $9 / 11$ and the war on terror-and that he wishes to inscribe the Rushdie affair as the inaugural event for the pattern of interpretation of the irreconcilability of liberal freedoms with Islam as the motivations for much of today's global conflict:

25. "Al-Qaida is to terror what the mafia is to crime. But its goal is not making money; its goal is remaking the world-and imposing its radical beliefs on people everywhere. The terrorists practice a fringe form of Islamic extremism that has been rejected by Muslim scholars and the vast majority of Muslim clerics - a fringe movement that perverts the peaceful teachings of Islam ... There are thousands of these terrorists in more than sixty countries. They are recruited from their own nations and neighborhoods, and brought to camps in places like Afghanistan where they are trained in the tactics of terror" (George W. Bush, speech to the House of Representatives, 20 September 2001).

26. Cf. Bülent Diken and Carsten Bagge Laurentsen, The Culture of Exception: Sociology Facing the Camp (London: Routledge, 2005); idem, "We Two Will Never Twin': Fundamentalism and the Politics of Security", Global Society, Vol. 20, No. 2 (2006), pp. 199-221; John Urry, "The Global Complexities of September 11th", Theory, Culture and Society, Vol. 19, No. 4 (2002), pp. 57-69. 
The burning book became an icon of the rage of Islam. Sent around the world by a multitude of photographers and TV cameras, the image proclaimed, "I am a portent of a new kind of conflict and of a new kind of world". ${ }^{27}$

It is only after 9/11 that the "new kind of world" emerged in positioning the "rage of Islam" as a dominant trope in the media, culture, politics and academic writing. The Rushdie affair was employed in order to create a popular archaeology in which it acted as the inaugural event for transnational Islamist dissent within the West, which would eventually lead to terrorism on a global scale. British cultural production, from novels and movies to autobiographies of ex-Islamists and newspaper disputes, has encoded the Rushdie affair within its recent memory, by which it reflects on itself as a multicultural state with transnational conjunctions. In these narrations, the past has been re-ambiguated in order to suit how the British public narrates a "globalised", in the sense of deterritorialised and interconnected, present to itself. The idiom of the literary has worked to differentiate these narrations, but at the same time a linear reading of fiction's early attention towards the topos of the home-grown Islamist has also enabled the linear trajectory of the story that leads the migrant from fatwa to jihad.

Malik's and Phillips' arguments are similar to the rhetoric of the "Islam in Europe" debate in 2007, in which Pascal Bruckner and Paul Cliteur flamingly denounced multiculturalism, which Bruckner called a reversed racism ${ }^{28}$ that would promote fundamentalist tendencies-which were here, again, rendered as cultural rather than as political threats.

But this recent discourse also includes self-narrations of representative British Muslims under titles such as "I used to be a book-burner" 29 in newspapers and TV documentaries, where the opposite is claimed and the Rushdie affair is historicised as a success, clearing the way for the development of a new kind of multicultural public sphere in which religious sensibilities can be seriously pleaded in public. Both the Rushdie affair and Islamist terrorism in the West are utilised in a debate about British, and European, public politics.

Some of the tropes that are recovered in the new "histories of British fundamentalism" can be found in the early attention of British fiction written in the 1990s, which can act as an archive for the contemporary political debate. ${ }^{30}$ Fictional works that played a role in this configuration include novels and movies by Hanif Kureishi, whose work has made the friction created by fundamentalist tendencies in migrant communities its topic in The Black Album (1995) and the film My Son the Fanatic (1998). Both Kureishi's Black Album and Zadie Smith's novel White Teeth (2000) address the Rushdie affair specifically in the context of British society.

27. Kenan Malik, From Fatwa to Jihad: The Rushdie Affair and its Legacy (London: Atlantic, 2009).

28. A collection of all essays of the "Islam in Europe" debate can be found on <http://www. signandsight.com/features/1167.html > (accessed 20 August 2009).

29. Cf. Jürgen Habermas, "Religion in the Public Sphere", European Journal of Philosophy, Vol. 14, No. 1 (2006), pp. 1-25.

30. Malik cites Monica Ali and Hanif Kureishi. 


\section{Imagining the Urban Islamist}

It is interesting to note the key role that fictional literature of the 1990 s plays in this new configuration of collective memory we see today. In the deliberation of society, fiction and art in general act as sites of reflexivity that can extend, contest, or differentiate commonsensical judgments.

Multicultural movies and novels in the 1990s narrated the problem of extremist Islam as one ingrained within the youth culture of the time, and with a potentially dangerous trajectory into the future. Zadie Smith's narrator in White Teeth (2001) notes the strange coincidence of the Rushdie affair with the escapist, non-verbal and supposedly all-inclusive rave culture of the late 1980s when she sketches the advance of a new street crew culture in London. The beginnings of radicalisation are located within the creation of a hybrid identity:

It was a new breed, just recently joining the ranks of other street crews: becks, B-boys, Indie kids, wide-boys, ravers, Acidheads [...], Nation Brothers, Raggas and Pakis; manifesting itself as a kind of cultural mongrel of the last three categories [...] Their ethos, their manifesto, if it could be called that, was equally a hybrid thing: Allah featured, but more as a collective big brother than a supreme being, a hard-as-fuck geezer who would fight in their corner if necessary. ${ }^{31}$

The appeal of this imagination of the self as Raggastani was that it turned a vulnerable identity into a potential menace-this reflects their creation, in the novel, as a response to open racism in the Britain of the 1980s:

[...] But no one fucked with them anymore because they looked like trouble. They looked like trouble in stereo. ${ }^{32}$

Smith's narrator uses a lyrical example when she alludes to the potentiality of danger that, at this stage in January 1989, seems comical. The character Millat and his crew take on a phantasmagoric quality identified with their specific gait, and are connected with a poetical image of millennial fear. ${ }^{33}$ In hindsight, this takes on the quality of a foreshadowing of the dominance of the Islamist problem in the 21st-century imaginary:

[...] A kind of glorified, funky limp like the slow, padding movement that Yeats imagined for his millennial beast. Ten years early, while the happy acid heads danced through the Summer of Love, Millat's Crew were slouching towards Bradford. ${ }^{34}$

The story of the Bradford book burning in Smith's novel is the story of a rupture, of a breach in the truest sense. After the event of the burning of the book, the halfcomic, half-serious menace of the hybrid Raggastani will die, and, with making

31. Zadie Smith, White Teeth (London: Penguin, 2001 (2000)), p. 231.

32. Ibid., p. 232.

33. The beast of Revelation, 13; cf. William Butler Yeats's Poem "The Second Coming" (1919), in Richard J. Finneran (ed.) The Collected Poems of W.B. Yeats (Ware: Wordsworth, 1994), p. 158.

34. Ibid. 
the decision to be a part of this performance of burning a book, Millat is forced to decide for or against mutually exclusive values. Alsana, the character of Millat's mother, makes this decision for her son in her rejection of his partaking in the Bradford event. She burns all of Millat's pop-culture treasures with the comment:

Either everything is sacred or nothing is. And if he starts burning other people's things, then he loses something sacred also. ${ }^{35}$

In White Teeth, the rupture of the book burning has momentarily delegitimised the idea of cultural hybridity. This simultaneous incarceration of an idea of cultural fusion, of the possibility of existing within one's differences, which calls up the main topoi of The Satanic Verses, inaugurates the advent of fundamentalism. This is positioned as developing out of anger about the denial of a hybrid identity within the British public sphere:

Millat recognized the anger, thought it recognized him, and grabbed it with both hands. ${ }^{36}$

In recent literature, both Kureishi's allusion to a terrorist attack on the London transport system in his 1995 novel The Black Album ${ }^{37}$ and Millat's slow and zigzag descent into Brit-made fundamentalism in Zadie Smith's White Teeth are called up as literary foreshadowing of the Al Qaeda-inspired 2005 terrorist attacks in London. What is also important to note in these fictional renderings is the focus on the trope of the self-converted British Islamist. The device of renaming often achieves this identity swap. Characters with English-sounding names like "Trevor Jones" re-route their identity with neo-authentic names like "Muhammad Shahabuddin Ali-Shah". ${ }^{38}$ The topos of self-conversion of second-generation immigrant, rock ' $\mathrm{n}$ ' roll-minded youngsters into Islamic fundamentalists represents this new subjectivity as deeply embedded in and evolving from the ideology of choice which has shaped Euro-American subjectivities since Romanticism, ${ }^{39}$ rather than stemming from an authentic wish for religious revelation. Other than the transformation of the hybrid "mongrel" of Smith's Millat discussed above, in Hanif Kureishi's Black Album the young fundamentalists seem a part of the urban postmodern lifestyle and counter-culture exactly through their total opposition to it. In an attempt to cover their already culturally hybrid heritage as Asian British, their self-conversion to Islam betrays a wish for unreachable authenticity. Rather than celebrating the Bhabhaian "third space" ${ }^{\prime 40}$ of their existence and its supposedly revolutionary potential, these globalised subjectivities within the West re-imagine their shape in a dangerous fantasy of cultural purity. In Kureishi's and Smith's novels, rather than resolving their own complexity, this wish for purity only entangles the identity of the characters in more intricate patterns of

35. Ibid., p. 233.

36. Ibid., p. 234.

37. Hanif Kureishi, The Black Album (London: Faber and Faber, 1995), p. 102ff.

38. Kureishi makes fun of the re-naming in The Black Album, p. 108, when he includes the name of Rushdie's fiercest Indian critic.

39. Cf. Andreas Reckwitz, Das Hybride Subjekt (Göttingen: Velbrück, 2006).

40. Cf. Homi Bhabha, The Location of Culture (London: Routledge, 1994). 
denial and camouflage. It is not presented as a route out of confusion, but paradoxically, into more, rather than less, anomie and anxiety of identity.

In the contemporary closure of remembering the Rushdie affair, the ongoing dispute of how the Rushdie affair is to be represented is overwritten by the creation of a lineage that leads from protest to bombs. While the memory of it has been transferred into cultural "material storage" ${ }^{\text {"11 }}$ in the form of movies and novels, the way the story of the Rushdie affair is told has the potential to be renewed-the same material which aided the writing of the Rushdie affair as part of a globalised remembering of $9 / 11$ and the war on terror at this point in historical time can also offer a close reading of the culturalising issues at stake in this context, for example in a re-assessment of representations of the individualist, pop-cultural streak of early neo-fundamentalism as opposed to a clash-of-cultures narrative. The from fatwa to jihad narrative sits on the link between social memory in the sense of the memory of a generation ${ }^{42}$ and the potential stores of cultural memory in the form of books and films which the same generation is at the moment creating. These literary idioms of making statements about society have seemingly foreshadowed the public remembering of the Rushdie affair after the 2005 London bombings, which were (pre-)imagined in The Black Album and in Patrick Neate's City of Tiny Lights (2005). However, owing to their capacities as fictional entities, which do not describe reality but open it up regarding discursive possibilities, they might have the capacity to re-ambiguate and differentiate the way we make sense of a situation of post-secular and pluralist conflicts, to which this text wishes to contribute as well.

\section{The Creation of a (G)Local Memory of the Rushdie Affair}

Remembering the Rushdie affair opened up the possibility for "memory work" on the phenomenon of British fundamentalism, its links to globalised Islamism as well as to British migrant identities and the politics of multiculturalism. By "memory work", I understand the concept developed by Johannes Fabian. ${ }^{43} \mathrm{He}$ describes memory work as a dialectical notion, with which he wished to stress the also disintegrative strands of a shared memory, which has to be constructed in order to be "narrated, exhibited, and performed". ${ }^{44}$ This production of cultural material that can store collective memory ${ }^{45}$ in an emergent "public historiography" develops within a situation of dispute and contestation. Fabian notes: "[...] such work has to be carried out in a field of tensions between positing and negating". ${ }^{46}$

In a dispute about the state of British multicultural politics, the Rushdie affair was employed as a marker by both the defenders and the critics of this policy, as I have shown above. Depending on the differing aims of commentators, it is posited in different ways, and different features of it are being negated-again, writing like this text being no exception. Fabian, here, stresses the important interlocking of remembering and forgetting-one is not possible without the other.

\footnotetext{
41. Assmann, Der lange Schatten der Vergangenheit, op. cit., p. 58.

42. Ibid., pp. 28-29.

43. Johannes Fabian, Memory against Culture (Durham, NC: Duke University Press, 2007), p. 78.

44. Ibid.

45. Cf. Assmann, Der lange Schatten der Vergangenheit, op. cit., p. 58.

46. Fabian, op. cit., p. 78.
} 
The paramount characteristic of this specific public historiography is its simultaneously global and local designation: regarding the Rushdie affair, British memory culture is representing the local as global and vice versa. The narrative that takes its trajectory from fatwa to jihad already presents a story of conflict within the multicultural society of Britain that demands a public debate-it riddles the idea of an integrated society by laying bare the ambiguous and unfinished construction sites of nation, identity, memory in Britain's post-colonial condition. ${ }^{47}$ Even if this narration seems to be employed to point to a grave danger to this society, it nevertheless points towards the fact of pluralism, as Habermas calls it, $^{48}$ which is the reality of European societies today. At the same time, it also points to the realities of transmigration and cultural hybridity-the cultural features of globalisation. ${ }^{49}$ But these global stories are taking place within Britain, with British subjects as their actors, and British cities as their set. What is created is a public historiography in which globalisation's frictions are played out within one city, within one street-a (g)local memory culture.

\section{Cultural Disjunctures and $(G)$ Local Memory}

As Salman Rushdie was forced to live in hiding until 1997 and the fatwa was never officially lifted, the issue of The Satanic Verses gained renewed media attention at intervals over the last 20 years. But at the height of the media attention in early 1989 the Rushdie affair came to be represented as a "rupture of the evident". 50 What was ruptured by the Rushdie affair was a simultaneously awakening epistemic undercurrent, in the West, that peace was entering the world with the rapid thawing of Cold War bloc geopolitics, as Fukuyama describes it in The End of History, and that this peace would be brought about by the global suffusion of cultural difference accompanying the spread of liberal democracy and capitalism. The idea of the West would succeed dialectically in overcoming cultural and ideological conflict. But the Rushdie affair was interpreted as a rupture in this thought experiment-though it could also be read as a new phase of the dialectical movement.

The British narrations which encode the Rushdie affair as a forerunner to Britain's share in a globalised jihad work to culturally identify the threat within the local-the outside enemy is at home, not outside, within the gates of the city. At the same time, they narrate the story of post-war, post-colonial Britain as one that is in the process of dispute over the shape of its multi-ethnic reality. This includes the search for new ways of convivial exchange which has to acknowledge the deterritorialised shapes of its subjects' identities, who might live on the territory of Britain, partly integrate, but also replicate community structures of spatially "distant" world areas, and communicate in translocal constellations. ${ }^{51}$

47. Cf. Homi K. Bhabha, "DissemiNation", in Homi K. Bhabha (ed.). Nation and Narration (London: Routledge, 1990), p. 300: "the nation reveals, in its ambivalent and vacillating representation, the ethnography of its own historicity and opens up the possibility of other narratives of the people and their difference".

48. Habermas, op. cit.

49. Cf. Writings by Homi Bhabha, Gayatri Chakravorty Spivak, Arjun Appadurai, Anna Lowenhapt Tsing, and Rey Chow.

50. Foucault, op. cit.

51. Neil Brenner, "Beyond State-centrism? Space, Territoriality and Geographical Scale in Globalization Studies", Theory and Society, Vol. 28, No. 1 (1999), pp. 40-50. 
These configurations render obsolete ideologies of nationality founded on a striving for homogenisation of territory, language, ethnicity, myth. With the fact of the (trans)migration of people and concepts, the self-narration of Britain is embedded within this process of migration as well. The home-grown dimension of global Islamist terrorism in the 21st century denies a rhetoric that wishes to designate to this phenomenon a place outside the Western social imaginary and the imagination of the nation as container and/or quasi-organic structure. In the war on terror rhetoric of the Bush administration, the terrorist subject had been configured as a global outsider. This outside designation is embodied most starkly by the creation of the Guantanamo Bay camp, but also by attempts to locate the site of spiritual extremism outside the West. In the British stories with a from fatwa to jihad trajectory, this outside location is countered with a remembering that makes causal narrative links with a recent past, or, in the fictional texts of the 1990s, prefigures a future now past. This observation leads me to speak of a (g)local memory of the Rushdie affair.

The narration of these global trajectories within the narration of the developments of subjectivity within Britain envelops the globalised story of radical Islamism within specific memory work. The Rushdie affair reveals how identity narrations within specific societies are incorporating and.localising the global "disjunctures" present. In this observation of the different features of the "global" in an eventalisation of the Rushdie affair, we find the interaction of three different, albeit interlinked, aspects of globalisation: (1) the American idiom of a global war on terror designates the global into an essentially placeless, though paradoxically targetable, "outside". ${ }^{53}$ In this respect, there is a discursive similarity to the likewise non-specific Islamist's idiom of global jihad, ${ }^{54}$ which rejects every existing social order in order to create its state of totalised Islam. The ideology of a discourse such as the global war on terror and global jihad are part of a discourse of globality which is essentially empty in its overdetermined placelessness, its state of everywhere and nowhere. ${ }^{55}$ This "outside" of thread and target is localised in a memory narrative of (2) British fundamentalism, once it is connected with specific stories that are linked to cultural identity. This British story re-works the tropes of the American and the jihadi idiom in a connection to its local imaginary of a narrated nation, which is itself contested by the historical ambivalence that its specific post-colonial history carries. ${ }^{56}$ It shows how the territory of a state takes on the quality of a node on and through which subjects move and construct their identities within translocal and transcultural networks, and therefore interrogates and questions the idea of national identity. Both these idioms and narrative, however, are instantiations of (3) statements about the current condition of cultures which describe them as globally disjunct, and which are, in many places, in many constellations, at this time re-routing their narrations, traditions,

52. Cf. Arjun Appadurai, Modernity at Large (Minneapolis, MN: University of Minnesota Press, 1996), pp. 35-36.

53. Cf. Rey Chow, The Age of the World Target (Durham, NC: Duke University Press, 2006).

54. Cf. Diken and Laurentsen, "We Two Will Never Twin", op. cit.

55. Cf. George Ritzer, The Globalization of Nothing (Thousand Oaks, London and New Delhi: Sage, 2007).

56. Cf. Bhabha, "DissemiNation", op. cit.; Judith Butler and Gayatri Chakravorty Spivak, Who Sings the Nation-state? Language, Politics, Belonging (Oxford, New York and Calcutta: Seagull, 2007). 
identities within increasingly translocal and transcultural spheres: the British narration of itself during the Rushdie affair and the Islamist terrorist attacks are one specific example of this latter re-configuration in an idiom of a translocal "postidentity". ${ }^{57}$ The Rushdie affair, in making it the inaugural event preceding later Islamist terrorism, has played the role of a symbolic nodal point for such memories, stories, and subjects of a society hosting specific "disjunct cultures" and their histories. When Saskia Sassen writes that

a good part of globalization consists of an enormous variety of microprocesses that begin to de-nationalize what had been constructed as national-whether policies, capital, political subjectivities, urban spaces, temporal frames, or any other variety of dynamics and domains ${ }^{58}$

the (g)local memory of the Rushdie affair is an example of a de-nationalising narrative of British society. In its structure as dispute about moral and (multi)cultural values, competing signifiers of cultural identity are enacted in a dispute about what a "narration of the nation", ${ }^{59}$ what societal integrative identity constructs could be in a globalised condition.

The connections of these different levels of "globalization" in which we exist open up a more general question: living within these conditions, what "ideoscapes $^{\prime \prime 60}$ can conduct convivial exchange?

\section{Shifting the Enlightenment}

When the values of the Enlightenment developed historically, the secular position was shaped to be utilised as diplomatic reasoning in a Europe torn apart by interreligious wars. ${ }^{61}$ What was displayed in the Western reaction during the Rushdie

57. For elaboration on such constructions which retain the term identity but delete its former designations, see Laura Chrisman, Postcolonial Contraventions: Cultural Readings of Race, Imperialisam and Transnationalism (Manchester: Manchester University Press, 2004); see also Paul Gilroy, Between Camps: Nations, Cultures and the Allure of Race (London: Routledge, 2004).

58. Saskia Sassen, Territory, Authority, Rights: From Medieval to Global Assemblages (Princeton: Princeton University Press, 2006), p. 1.

59. Here and in the remainder of the text I use the term "nation" in its open interpretation as a community of affiliation by living in a common territory under common legislation, not in the sense of belonging to a "nation" in the sense of ethnicity, or as ethnicity wedded to territory (in the sense of Volk). The complex relationship concerning questions of national ethos, ethnicity, and history related to the differentiation between "Englishness" and "Britishness" cannot, for the sake of conciseness, be part of this discussion-however, I am aware of the underlying problem of the combination of the terms "British" and "nation-state" if one defines the word nation in the sense of ethnicity.

60. Appadurai, op. cit.: "Ideoscapes are also concentrations of images, but they are often directly political and frequently have to do with the ideologies of states and the counterideologies of movements explicitly oriented to capturing state power or a piece of it. These ideoscapes are composed of elements of the Enlightenment worldview, which consists of a chain of ideas, terms and images, including freedom, welfare, rights, sovereignty, representation, and the master term democracy. The master narrative of the Enlightenment (and its many variants in Britain, France and the United States) was constructed with a certain internal logic and presupposed a certain relationship between reading, representation, and the public sphere. But the diaspora of these terms and images across the world, especially since the 19th century, has loosened the internal coherence that held them together in a Euro-American master narrative and provided instead a loosely structured synopticon of politics, in which different nation-states, as part of their evolution, have organized their political cultures around different keywords."

61. Cf. Charles Taylor, A Secular Age (Cambridge, MA and London: Belknap, 2007), p. $159 \mathrm{ff}$. 
affair can be seen as a display of the rhetoric of pathos this kind of enlightened reason was defended with. An ideologically motivated re-claiming of the Enlightenment is stated with the same intensity as are religious certainties. ${ }^{62}$

By claiming the Enlightenment as the core of Western, Judaeo-Christian identity, this foundational narrative expels Islam from the project of modernity-if we see the values of the Enlightenment as a core of this project. Islam is discursively proscribed as a tradition, which the evolving reflexivity of the modern has to rule out and overcome, in a move towards an ever-postponed "End of History".

Recently, theorists demanding a post-secular turn of public reasoning, foremost among them Jürgen Habermas, have thought along similar lines, but with a different aim: where an identity politics of re-claiming the Enlightenment as Western cements an antagonistic set-up in which an Islam perceived as traditionalist cannot be dealt with on a rational basis, Habermas's project aims at renewing a communicative basis for Europe's uneasily pluralist societies. By asking for the possibility of post-secular public reason, Habermas wishes to transform the task of translation that had been put forward in Rawls' Public Reason. Rather than demanding religious arguments to fulfil the task of transforming themselves into secular reasoning, which can then be pleaded in public in a secular liberal state, Habermas asks the forum of the secular majority to translate cultural and religious arguments into secular ones. ${ }^{63}$ In this way, arguments that previously could not be uttered are supposed to take on a more general validity and can be rescued from becoming zones of alienation among groups within society. This is to preclude the disintegrative function that such untranslatable claims within pluralist societies contain-the Rushdie affair would be a good example of this effect of untranslatability. But, as I will point out below, Habermas's call for translation is in danger of entangling itself in the culturalisation of migrant subjectivities as well as that of host societies' mainstream population. It is therefore important to asses his heuristics for the post-secular, in which Habermas moves Christian tradition into the forefront of the ongoing project of modernity:

For the normative self-understanding of modernity, Christianity has functioned as more than just a precursor or a catalyst. Universalistic egalitarianism, from which sprang the ideals of freedom and a collective life in solidarity, the autonomous conduct of life and emancipation, the individual morality of conscience, human rights and democracy, is the direct legacy of the Judaic ethic of justice and the Christian ethic of love. This legacy, substantially unchanged, has been the object of a continual critical reappropriation and reinterpretation. $U p$ to this very day there is no alternative to it. And in the light of current challenges of a post-national constellation, we must draw sustenance now, as in the past, from this substance. Everything else is idle postmodern talk. ${ }^{64}$

Arguing for a post-secular reason by strengthening Western identity as Christian would mean, in my interpretation of Habermas's aim, to transform the Other into

62. Cf. Richard Webster, A Short History of Blasphemy (Southwold: Orwell Press, 1990).

63. Cf. Habermas, op. cit., pp. 6ff., 15.

64. Jürgen Habermas, "A Conversation about God and the World", in E. Mendietta (ed.), Religion and Rationality: Essays on Reason, God, and Modernity (Cambridge: Polity, 2002), p. 149. For a critical discussion of Habermas's post-secularism see Austin Harrington, "Habermas and the 'Post-secular Society'", European Journal of Social Theory, Vol. 10, No. 4 (2007), pp. 543-560. 
another, i.e. concerning the example of this text, the alien of Islam into an alter, maybe even an alter ego of Christianity. But whether this move would be able to create a communicative basis for value disputes between the religious of different kinds, and the non-religious of different kinds, remains questionable, because Habermas, arguing for inclusion of plurality, risks writing the Other out as a result of the focus on European exceptionalism. This is the point behind my interpretation of Habermas's project of post-secular reason as a configuration of alterities: even if Islam can be positioned as an alter ego, the ego of this alter would be the West. In this configuration, the West cannot be written out of its role as the heart and motor of global modernity. In this sense, Habermas's argument, though attempting to include the Other's value system, can only fully accept it if it becomes "translatable" into the Western tradition, with its Christian heritage performatively stressed. Habermas's "religious turn" is, in this sense, a turn towards the Christianness of Western modernity, which at the same time is positioned as the only kind of modernity thinkable. It is therefore highly problematic in the light of more constructivist and post-colonial conceptions of pluralism and modernities. ${ }^{65}$ It shares the argumentative idiom brought forward in the defence of Salman Rushdie after the fatwa, and shows how the values which were traditionally seen as universal human values are now re-culturalised as not only universal and human but foremost Christian. The actual attempt to embrace pluralism in the shape of a dialogue between the rational and the religious, and to devalue the strong claim of the exclusive validity of Western neo-Kantian thought, leads to a strong claim about the exceptionalism of the Western Christian tradition.

If we try to disaggregate the cultural entanglements of the Rushdie conflict to a dispute of opposing normative values, we can analyse it as the interlocking of a double pair of negative and positive freedoms: the positive secular freedom of free speech is countered by a post-secular or religious freedom to be spared this kind of free speech which affronts the sacred-the argument underlying the Muslim demand to extend existing British blasphemy laws to include Islam. The positive freedom to enact religious sensitivities is countered by the negative secular freedom to be spared the public enactment of this religious sensitivity. It is this claim the right to be spared religious motives and sensibilities that prompted the secular liberal mainstream public-and the states of Western Europe as they stood against Iran after the fatwa-to formulate their rejection of the deadly provocation of the fatwa.

In this double-coupling antagonistic configuration of freedoms, decisions have to be made as to which freedom rights are possible to plead above others, which meaning of freedom is to be the hegemonic one. For the public, communicative decision power in this question comes in the form of media attention. In the case of the Rushdie affair, the verdict of the British and Western media was clear. After Khomeini's pronouncement of a fatwa-an international incitement to murder-the Muslim demands were represented as having de-validated themselves from a dispute about freedom of speech, as the dispute had become one about the freedom to live.

At a level of reflexivity above remembering the Rushdie affair as an artefact of conflict and a description of identity within a (g)local setting, we find an

65. Shmuel N. Eisenstadt (ed.), Patterns of Modernity (New York: New York University Press, 1987). 
antagonistic rhetoric, which has culturalised and perhaps re-sacralised the standoff between the West and Islam. This rhetoric was tested in the open-letter campaigns that defended Salman Rushdie and free speech internationally in the $1990 \mathrm{~s}^{66}$ and has persisted after $9 / 11$ whenever value conflicts with Muslims seem to flare up in Europe. In these letter campaigns and public commentaries, many stressed the foundational Christianity of the Enlightenment as opposed to the Islamic tradition which was presented as lacking the dialogic features supposedly inherent in Bible hermeneutics. ${ }^{67}$ The latter were represented as enabling features of modern reflexive thought. This argumentation, however, is to be seen as a defence move in the strongest sense. It is a part of a recent Western identity politics. Paradoxically, the writers and intellectuals who wished to defend the free speech of Salman Rushdie and the universal value of this freedom have helped those critics who wish to deconstruct their universal validity claim. By assigning the ability to develop this freedom to the heritage of a Christian West, and opposing it rhetorically to an Islam constructed as a monolithic, monologic, anti-modern entity, they have involuntarily facilitated the deconstruction of the idea of universal, human values.

In this rhetorical move, Enlightenment values are positioned within the Western power centre, and, by stressing this historical link, can further help its critics who attempt to legitimise its rejection by stressing the same historical link. This has been the case in a strand of criticism that employs Carl Schmitt's analysis of humanism as hegemonic power politics. ${ }^{68}$ In a reversal of the argument of European exceptionalism, this writing asks why the values of the West should be of relevance for a culture that has been "Othered" by it. Critics such as Ahmed Akbar state that "ethno-religious revivalism or fundamentalism feeds" on such theorising. ${ }^{69}$ The claiming of the Enlightenment as Western is rejected for this reason by An-Na'im, who states that "Human rights may emanate from a Western tradition, but do not belong to the West". ${ }^{70}$

In every case a call for translatability would be welcome-where critics see the effect of the multicultural politics of recent decades as having failed in this project of translation. In the view of secularists, multiculturalism has created a victim culture and a black box of respect, in which what is pleaded as cultural sensibility

66. Cf. Thierry Chervel (ed.), Redefreiheit ist das Leben: Briefe an Salman Rushdie (Munich and Zurich: Piper, 1992); English-language edition: Steven MacDonogh (ed.), The Rushdie Letters: Freedom to Speak, Freedom to Write (Lincoln: Nebraska University Press, 1993); for an argument-structure discussion of the letters see Nicole Falkenhayner, "The Rushdie-controversy as a Transnational Dispute-Reflexes and Reflexivity in the Letter Campaign for Free Speech", Talk at the GSA Annual Meeting 2008, St. Paul, Minnesota.

67. I.e. Margaret Atwood, in her letter entitled, in the German monograph edition, "Traum im Kopf eines Taugenichts" [Dream in the Head of a No-good Guy (my translation)], by which she refers to the protagonist Gibreel who dreams the passages on Mahound's revelations/imaginations. She calls Christianity a "house with many living quarters". In her argumentation, Christianity is supposed to include criticism as an inherent feature. In Chervel, op. cit., pp. 62-66.

68. Cf. Carl Schmitt, Politische Theologie: Vier Kapitel zur Lehre von der Souveränität (Berlin: Duncker and Humboldt, 1922); W. Rasch, "Human Rights as Geopolitics", Cultural Critique, Vol. 54 (2003), pp. 19-38.

69. Ahmed Akbar: Postmodernism and Islam: Predicament and Promise (London: Routledge, 1992), p. 13; Richard Wolin, The Seduction of Unreason: The Intellectual Romance with Fascism from Nietzsche to Postmodernism (Princeton: Princeton University Press, 2004).

70. Abdullahi Ahmed An-Na'im, "Expanding the Limits of Imagination: Human Rights from a Participatory Approach to New Multilateralism", in Michael G. Schecter (ed.), Innovation in Multilateralism (Tokyo, New York and Paris: United Nations University Press, 1998), p. 205; emphasis in original. 
has to be respected while staying untouched by attempts at translation. Interacting with the other cultural realm in the sense of criticising it is seen as an affront to tolerance. But both the demand of a strong multiculturalism for acceptance of nonassimilation also to fundamental values, and the demand of value assimilation of strong secularists operate from a strong culturalist stance. This stance dismisses the always already hybridised state of cultures ${ }^{71}$ in a global present, generally, and the multitude of Islamic traditions, specifically.

In Habermas's move towards a post-secular assessment of modernity, a strong Western identity that is aware of its cultural heritage is positioned as the opponent of a likewise strong Islamic identity that is aware of its cultural heritage-between these two "clarified" identities, the communicative re-assessment of a post-secular society can emerge, a proposal that seems akin to Bassam Tibi's call for an "Asabiyya/esprit de corps" ${ }^{\prime 72}$ for Europe-the development of a strong code of values. The problem with Habermas's and Tibi's ideal might lie simply in the unified shape of this Islamic opponent, which in political reality exists as little as a unified West that would be able to rally behind one Christian legacy.

As Rushdie's contested writing reminds us, these constructed "clarities" are mutable, prone to hide their also shifting natures, and tend to react with aggression when ridiculed. Habermas's reduction of the genealogy of Enlightenment values to "the Christian ethics of Love" and the "Judaic ethics of Justice" is an example of the creation of cultural memory as identity construction, the process of which demands productive forgetting, as I have noted above. To what space is the actively forgotten third figure of the trinity of monotheisms assigned in this configuration?

Olivier Roy has pointed out that the culturalisation of radical Islam was the great mistake of the West. ${ }^{73}$ Western neo-fundamentalist Muslims, or, as he calls them, born-again Muslims, ${ }^{74}$ develop their imaginary out of the mechanisms of individualism rather than out of any particular Islamic tradition-an observation that we can also find in the imaginary of the literary texts discussed above. It is true that neo-fundamentalism creates a rift in the fabric of society, but this

[...] has little to do, however, with the "clash of civilizations" [...] this Islam [...] is an abstract identity, with no roots in a particular society or culture. ${ }^{75}$

This Islam, Roy continues, does not look for a place in the public sphere of the stateas the British Muslims' protest in the Satanic Verses had, if we wish to interpret their aims positively. Rather, for the sake of the teleological certainty of global jihad it has abandoned the public sphere other than the phantasmagoric state of Islam:

The state has no grip on it, because the two are in different worlds. ${ }^{76}$

71. Cf. Timothy Brennan, "The Cuts of Language: The East/West of North/South", Public Culture, Vol. 13, No. 1 (2001), pp. 39-63, esp. his reading of Rey Chow, pp. 52-53.

72. Bassam Tibi, Die islamische Herausforderung (Darmstadt: WBG, 2007), pp. 43-47.

73. Cf. Olivier Roy, Le Croisant et le chaos (Paris: Hachette, 2007).

74. Olivier Roy, Secularism Confronts Islam (trans. George Holoch) (New York: Columbia University Press), p. 77.

75. Ibid.

76. Ibid. 
The creation of a double semiotic inscription of the public space as both secular and sacred space is of importance for a post-secular subjectivity in Habermas's sense-but for the adherent jihadist, the public space of the state exists only as a place to be voided by destruction in the image of the exploding bomb. ${ }^{77}$ Extending Roy's perspective, the trajectory from fatwa to jihad is not without danger. It is debatable whether the protest of British Muslims is to be inscribed into the teleology of global jihad, even if the will to self-confident integration stressed by the institutions British Muslims have set up since their inaugural protest is a topic of debate as well. But the narrative that leads subjectivities from the outrage about a book, and a self-description as British Muslims, into global jihad exemplifies a closure that has bracketed Western Islam within the markers of its most anti-humanist, anti-state, and anti-Semitic form. At the same time, the public visibility and discursive construction of religious affiliation as identity marker has bracketed migrant subjectivities within their religious heritage as a totalising identity. Habermas's task of translator begins before translating between Islam and the West-it first has to break apart the monolithic shell that has developed around multiplicity in the creation of the antagonistic configuration by both sides.

\section{Conclusion}

The complexities of political, cultural and religious pluralism seem to have dropped on the liberal mindset just as the characters Gibreel Farishta and Saladin Chamcha tumble from an exploded Air India jet in The Satanic Verses. Falling from high altitude towards the British shore, they are entangled in an intricate fabric of apparitions, songs, myths and sheer speed that unravels their former identities. Thus, in this paper I wished to point to the complexities that tend to become conflated in the generalisations of confrontational rhetoric-and which in generalisations, can influence identity constructions. I have revisited the temporal marker 1989 which has been singled out and inscribed as the year of a rupture. As such, bestowed with the contrasting premediations of the clash of civilisations or the end of history, 1989 designates a global event from which stories of the present seek their legitimising genealogy. I have shown how public historiography in Britain has created a narration of collective memory out of the Rushdie affair. This representation designates Britain as a territorial state composed of de-territorialised subjects, cultures and imaginations with the capacity for more, rather than less, cultural exchange than policies of mere "respect" would demand-if we chose to read it against the grain of its function as the signal for societal disintegration. It shows the Janus-faced discourse about multiculturalism today, which on the one hand cherishes the difference of culture as long as it is contained in a marginal sphere, but rejects it once it demands to partake in the public space-where suddenly the formerly rejected claim to assimilation becomes a noisy call. The judgements about pluralism and the global threat of fundamentalist Islam have been assessed via arguments which can be traced back to the Rushdie affair, and can be linked to recent post-secular theorising. In these, calls for the translation of knowledge and conviction as yet underrepresented in the public sphere should be stressed-while one should regard the

77. I thank Michael Nau for pointing this out to me in discussion. 
reification of the Enlightenment as Western, Christian heritage with caution. Especially when one wishes to retain a universal humanism as an ideal, embedding it in Christian ethics solely is not helpful. Reflecting the cultural "disjunctures" of the global present and the travel potential that Enlightenment's values have when they are unhinged from their historical origin, the West can no longer claim them without constricting their validity within non-Western settings, or non-Western mindsets. These discursive and symbolic movements in various idioms of knowledge creation are linked to the larger discourse in which we have to observe how societies will form their identity and narrate it to themselves in the global present of transcultural migration of people and ideas-and with which rights they will bestow their migrant subjects and thus shape their (g)local social reality. 